\title{
EVENT TOURISM DEMAND AND SELECTED MACROECONOMIC VARIABLES: AN ECONOMETRICS VIEW OF THE LONG-RUN AND SHORT-RUN RELATIONSHIPS
}

\author{
Sally Ann Yu-Ing Yap* \\ Universiti Malaysia Sarawak \\ Norazirah Ayob \\ Universiti Malaysia Sarawak \\ Chin-Hong Puah \\ Universiti Malaysia Sarawak
}

\begin{abstract}
Assessing the substantial economic benefits of event tourism will provide insight into the effectiveness of tourism event in Malaysia. The significance of the tourism event sector has the potential to boost Malaysia's economic growth, increase the arrival of international tourists, increase tourist expenditure and further job creations. This study empirically investigates determinants of event tourism demand in Malaysia during the period of 1991Q1 to 2016Q4. The Autoregressive Distributed Lag (ARDL) technique is used to find the longrun cointegration relationships of the model. The model is further tested by employing diagnostic tests (Normality test, Serial Autocorrelation, Heteroscedasticity and Ramsey's RESET test) and stability tests (CUSUM and CUSUMSQ). The empirical analysis of the bounds test indicates that there is a long-run cointegration among the variables under study. Besides that, the ARDL model produces reliable results, as all of the computed coefficients of the independent variables are statistically significant with the expected signs. The findings are consistent with economic theory and the model passed all of the diagnostic tests. The findings of this study imply that event demand can be improved significantly when government spending, the exchange rate and tourist receipts increase and the crude oil price decreases. Hence, government authorities and the private sector should create an integrated plan to enhance the profit gained through the Malaysian economy from event tourism.
\end{abstract}

Keywords: Event tourism demand; ARDL model; Malaysia.

Received: 22 January 2019

Accepted: 1 October 2019

\section{INTRODUCTION}

Tourism is one of the fastest moving and significant economic sectors of today's global industries (Kadir \& Karim, 2012; Li, Mahmood, Abdullah \& Chuan, 2013; Lean, Chong \& Hooy, 2014). The tourism industry in Malaysia has performed positively, as reflected in the constant development of

\footnotetext{
* Corresponding author: Sally Ann Yu-Ing Yap, Faculty of Economics \& Business, Universiti Malaysia Sarawak, 94300 Kota Samarahan, Sarawak, Malaysia. Email: sallyannyap92@gmail.com
} 
visitor arrivals and visitor receipts (Kadir \& Karim, 2012). Apart from that, the income obtained from international tourism receipt and tourist arrival have become a source of gain for both the private and public sectors through the multiplier effect, which has resulted in economic expansion. Also, the progress of the tourism industry has also positively subsidised the development of activities in other sub-sectors, which are mainly the festivals and events that have been staged and planned.

Before the 1970s, economic prosperity, based on the agricultural and manufacturing sectors, was the backbone of the Malaysian economy. Both of these sectors led to Malaysia's economic growth and have been major contributors to the nation's income and export earnings. Soon after Malaysia's independence in 1957, the focus of the economy shifted to industrialisation as the key driver for the nation's growth. This structural change in the Malaysian economy caused the relative importance of the agricultural sector to decline and the economy experienced diversification. According to Othman and Jafari (2014), the share of the agricultural sector to Malaysia's GDP shrunk pronouncedly from 30 percent in the 1970s to only 7 percent in 2013. Meanwhile, the tourism industry has become one of the growing industries, however, the role of tourism growth in earlier years was considered as non-growth oriented. According to Li et al. (2013), tourism was stimulated in the mid-1970s as Malaysia's economy experienced diversification and became less reliant on exported goods. Since then, Malaysia's tourism income started to develop tremendously, due in part, to the great expansion of the tourism industry globally. Therefore, tourism is now listed as the second-largest income contributor of foreign exchange in Malaysia after manufacturing sector (Li et al., 2013).

Today, event tourism has listed as one of the highlighted economic sectors among the various tourism sub-sectors. Events are a special component of tourism in Malaysia (Yusof, Fazil, Mohamed, Ibrahim \& Talib, 2015; Ayob \& Wahid, 2016) and serve as a unique form of tourist attraction. Currently, in Malaysia, more festivals and special event are being developed by the Malaysian tourism authorities and both the government and private sectors as additional products to attract tourist arrivals into Malaysia (Ayob, 2003; Yusof et al., 2015). Generally, the cumulative development of festivals and special events is due to leisure-oriented lifestyle among Malaysians, Malaysia's economic prosperity, and also due to emerging global communication.

According to Getz (2008), Cibinskiene (2012), Oklobdzija (2015) and Getz and Page (2016) events are key motivators for tourism, indicating that they can significantly influence the growth of a destination. The definition of event tourism has been debated by several researchers. Although event tourism is becoming more competitive globally, the field of event tourism is now so vast that it is impossible to deliver a single description of the term. This industry is a unique sub sector of festivals that emphasize on the significance of the events toward tourism (Getz, 2012). As stated by Getz (1989), event tourism can be described as "the systematic planning, development and marketing of events for tourist attractions" (p. 133). Main examples of event tourism are; business events, sporting events, festivals and cultural events and entertainment events (Ayob \& Wahid, 2016; Getz \& Page, 2016).

Events in Malaysia have shown an increasing trend over recent years. It is claimed that Malaysia's event tourism started to flourish from around the year 1990, where many festivals and events were organised in conjunction with the country's first themed tourism year', which is Visit Malaysia Year'90. The growing success of event tourism in Malaysia can be observed from the introduction 
of the first and successful sporting event held in the country; the XVI Commonwealth Games 1998, also known as the KL98 Games, which was followed by other mega-events such as the F1 Grand Prix. Until the present day, the popularity and variety of such activities in Malaysia have increased extensively. Nevertheless, event tourism in Malaysia should still be considered as a developing sector, unlike in other countries, such as Australia and Singapore, where their event tourism can be claimed to be advanced and developed (Ayob \& Wahid, 2016). Hence, an exploration of event tourism demand is needed, which begs the question; What factors affect event tourism demand in Malaysia? The objective of this paper is to examine the relationships between event demand and selected macroeconomic variables, namely; tourist receipts, the exchange rate, government expenditure and the crude oil price.

This paper is organised as follows. Section 2 summarises the theoretical and empirical findings linked to the topics examined. Section 3 explains the methodology that is used to conduct the empirical analysis. Section 4 clarifies the model to be estimated, the data employed and explain the empirical outcomes that were obtained. Section 5 deals with concluding remarks and policy recommendations.

\section{LITERATURE REVIEW}

\subsection{Event Demand Investigations}

As discussed above, event tourism highlighted as a significant element of Malaysia's tourism sector. However, to achieve the maximum potential of event tourism development, various aspects of the sector need to be better managed, monitored and researched to ensure the sustainability of event tourism. The investigation of event tourism demand for Malaysia has become a popular area of study over recent decades. The growing number of past studies has demonstrated an increasing interest in estimating the event tourism demand model. However, the empirical literature concerning the accurateness of event tourism demand estimations has always been inadequate due to the outcomes of earlier studies being inconsistent (Kadir, Abdullah \& Nayan 2008; Kusni, Kadir $\&$ Nayan, 2013). There have been, until now, mixed findings that have existed in the event tourism demand model.

Additionally, this study is distinctive in the sense that for the first time there is an exploration of the association between event tourism demand and macroeconomic variables. Thus, the empirical outcomes offer suggestions to reflect on the effectiveness of tourism promotion strategies. Researchers have rarely employed time series analysis to examine the factors related to the field of event tourism demand. Apart from this, the association between event tourism and other economic variables is based on the tourism demand theory and model. The model constructed in past literature stated that price and income factors probably played an important role in determining the demand of tourism (Habibi, Rahim, Ramchandran \& Chin, 2009; Ooi, Hooy \& Som, 2013). Hence, this study examines the type of causality relationship among these variables on event tourism and tourism receipts, as well as other control variables.

In addition, several academicians (McArdle, 1998; Ayob, 2003; Said \& Ayob, 2005) have attempted to evaluate the field of event tourism study by employing temporal, spatial and thematic approaches to investigate the supply side of the event tourism field. Besides that, there have also 
been studies regarding the evaluation of the economic impact of events using the Computable General Equilibrium (CGE) and input-output (I-O) approaches. Nevertheless, only a limited amount of empirical investigation has so far been carried out employing the latest empirical approaches in event tourism study to investigate the determinants of event tourism. This is because understanding the factors underlying event tourism demand is important to enhance the economic contribution of the sub-sector.

\section{2. $\quad$ Empirical Studies on Tourism Demand}

The term 'tourism demand' is commonly referred as the amount of tourism goods and services that customers are keen and able to consume throughout a specific period. Existing literature has revealed that the determinant influences that might affect the quantity of tourism demanded, such as; the income of the consumer, the exchange rate, expenditure on tourism advertising, the tastes of the consumer, tourism prices in competing destinations, and transportation costs. However, it is noted that the availability of empirical data might be limited as not all of the variables are employed in tourism demand studies. Recently, there has been a growing interest in assessing the model of tourism demand (Salleh, Law, Ramachandran, Shuib \& Noor, 2008; Chaitip \& Chaiboonsri, 2009; Habibi et al., 2009; Muchapondwa \& Pimhidzai, 2011; Kusni et al., 2013; Thien, Puah, Hassan \& Arip, 2015).

A study reported by Thien et al. (2015) used Error-Correction Model (ECM) analysis by engaging quarterly data from the year 2000Q1 to 2013Q4. The empirical findings indicated the existence of a long-run association between Thailand's tourism demand for Malaysia and the independent variables, namely; Thailand's real income, travel costs and the exchange rate. This implies that; a rising income for Thailand, an appreciation of Thailand's currency and a rise in the cost of travelling will induce more Thai travellers to Malaysia. A similar study was undertaken by Salleh et al., (2008) which emphasised on the short-run and long-run relationship of the factors of Malaysia's tourism demand by examining the ARDL method and found that the major influences of long-run tourism demand were the price, the cost of travelling and the income level of travellers.

The same ARDL approach, was also employed in the studies indicated by Chaitip and Chaiboonsri (2009) and Muchapondwa and Pimhidzai (2011). In the study of Chaitip and Chaiboonsri (2009), the findings showed that income growth was positively correlated towards international tourist inflows in the long-run. However, the impacts among the exchange rate, low transportation costs, and exchange rate risk and the level of Thailand's tourist arrivals were negatively correlated. Besides that, Muchapondwa and Pimhidzai (2011) showed that there were significant impacts between taste formation, transportation costs, income growth, the types of the event held and the level of international tourist arrivals.

Apart from that, Habibi et al. (2009) used the GMM-DIFF estimator to investigate tourism demand for Malaysia by including the level of tourist arrivals, the tourist's income, population, relative prices and transportation costs. The empirical results showed that prices and the number of tourist arrivals were significantly negatively correlated. This indicated that an increase in prices would discourage the arrival of tourists into Malaysia. On the other hand, the study of Kusni et al. (2013) showed that both price and income factors significantly influenced the demand of tourism for Malaysia, with the outcome of income being positive and prices negative with regard to demand. 
However, both of these studies shared the similarity of using both a fixed-effects model and a random-effects model.

\section{MODEL, DATA AND METHODOLOGY}

The data used in this study were quarterly data for over the period 1991Q1 to 2016Q4. The data were obtained from the publication of the calendar of tourism events held in Malaysia that was extracted from the Ministry of Tourism, Putrajaya. The data on tourism receipt, government expenditure, the exchange rate and the crude oil price were obtained from the CEIC database. The following function was used to examine tourism event demand in Malaysia:

\section{$E V E N T=f(T R E C E I P T, E X C, G O V X, C O P)$}

Where EVENT is the measure of event demand in Malaysia. TRECEIPT is the measure of the income of the tourists generated in their origin country. EXC is the measure of the exchange rate between the US (United States) and Malaysia. GOVX represents the level of event promotion allocated by government spending. COP proxies travel or transportation costs.

The expected sign for the relationship between tourist receipts with event demand is positive. This specifies that an increase in tourist's income will motivate tourists to travel and spend more on goods and services.

Besides that, the exchange rate is expected to obtain either a positive or a negative association towards event demand. An appreciation of the Malaysian Ringgit will stimulate tourists to travel to Malaysia. However, a depreciation of the Malaysian Ringgit will discourage tourists from travelling to Malaysia.

Meanwhile, the presence of a positive association between government expenditure and event demand is expected. A higher allocation of government expenditure on infrastructure and event promotion will increase the number of tourists travelling to Malaysia who will indirectly demand further events hosted in the country.

Either a positive or a negative association is expected to occur among the price of the crude oil and event demand. This indicates that rising price of crude oil will increase the cost of airfares together with transportation costs which will discourage tourist from travelling to Malaysia. This may indirectly decrease the demand for events hosted in Malaysia. However, a decrease in the crude oil price will boost the number of tourists travelling to Malaysia because airfares and transportation costs will be cheaper. Therefore, this may encourage tourists to demand more tourism-related goods and services.

The empirical analysis procedure started by investigating the stationarity of the variables applying both the Augmented Dickey-Fuller (ADF) unit root test (1981) and the Phillips-Peron (PP) unit root test (1988). Then, the Autoregressive Distributed Lag (ARDL) technique, presented by Pesaran et al. (2001) was used, after identifying a mixture of I(0) and I(1) regressors. Besides, the ARDL approach is valid irrespective of the order of integration and is also suitable for use with small sample sizes (Narayan, 2005). However, following Menegaki (2019), who argued that it was 
not possible to proceed with the ARDL approach with the presence of I(2) variables in the computed unit root. This implies that the ARDL approach can only proceed in the existence of mixed I(0) and I(1) variables, depend on the hypothesis by Pesaran et al. (2001). A representation of ARDL equation is expressed as follows:

$$
\begin{aligned}
\Delta \text { LEVENT }_{t}= & \alpha_{0}+\sum_{i=1}^{n} \alpha_{1 i} \Delta L E V E N T_{t-i}+\sum_{i=0}^{n} \alpha{ }_{2 i} \Delta L_{\text {TRECEIPT }}+\sum_{t-i}+\sum_{i=0}^{n} \alpha{ }_{3 i} \Delta L E X C_{t-i} \\
& +\sum_{i=0}^{n} \alpha_{4 i} \Delta L G O V X_{t-i}+\sum_{i=0}^{n} \alpha_{5 i} \Delta L C O P_{t-i}+\beta_{1} L_{E V E N T}+\beta_{t-1} L_{T R E C E I P T}+ \\
& \beta_{3} L E X C_{t-1}+\beta_{4} L G O V X_{t-1}+\beta_{5} L C O P_{t-1}+e_{t}
\end{aligned}
$$

To evaluate the existence of long-run associations between LEVENT, LTRECEIPT, LEXC, LGOVX and $L C O P$, the bounds testing procedure using the critical values from Narayan (2005) was adopted here. The bounds testing technique was depending on the F-statistic. The F-statistic tests indicate that the proposition of no cointegration between the variables against the occurrence of cointegration among the variables. The hypothesis is shown as follows:

$H_{0}: \beta_{1}=\beta_{2}=\beta_{3}=\beta_{4}=0$ (There is no cointegration among the variables)

$H_{1}: \beta_{1} \neq \beta_{2} \neq \beta_{3} \neq \beta_{4}=0$ (There is cointegration among the variables)

There are two critical values under Narayan (2005), for the cointegrating test. Assuming that the lower critical bound for all of the variables under study are at $\mathrm{I}(0)$, indicate that no cointegrating identified among the variables existed. Besides that, assuming the upper bound for all of the variables under study are at I(1), indicate that the existence of cointegration between the variables. As the computed F-statistic lies above the upper bound critical value, then the rejected $\mathrm{H}_{0}$ hypothesis is identified. This means that the cointegrating variables are occurred. Besides that, when the F-statistic lies below the lower bound critical value, then the $\mathrm{H}_{0}$ hypothesis is accepted. This indicates that no cointegration identified. When the calculated F-statistics lies between the upper and lower bound critical statistic, hence, the results are inconclusive.

Once the long-run relationship was estimated, the computed Granger Causality test was obtained from the short-run testing procedures, before proceeding with the diagnostic tests (Normality test, $\mathrm{ARCH}$ test, LM test, and the RESET test) and the stability test.

Primarily, this study is quantitative research in its nature utilising secondary data collected from various government reports and documents. In the case of the data on the total number of events held per year, there was no ready data or information available for the researcher. Hence, to obtain the desired data on tourism events and festivals held in Malaysia since 1991, the researcher examined the annually published Calendar of Events kept at Tourism Malaysia's main library in Putrajaya.

The list of events and descriptions obtained was considered as raw data and not suitable to be analysed. Figure 1 presents the process of data preparation for analysis. From the physical annually published Calendar of Events, the researcher extracted all of the events, a total of 6144 events between the years 1991-2016 and recorded them manually into a Microsoft Excel file. Initial event classifications were established to assist the researcher to understand the nature of the numerous events recorded. At the same time, the events were filtered and cleaned out to reduce redundancies and insignificant data. Examples of this process were the birthday records of Sultans or Kings, and where the same religious celebrations were celebrated in more than one state. The researcher noted 
the importance of actively reading through the entire Calendar of Events at least twice for familiarisation and to better understand past events. Then the data was transposed into yearly data as presented in Figure 1.

Figure 1: The Number of Tourism Events in Malaysia, 1991-2016

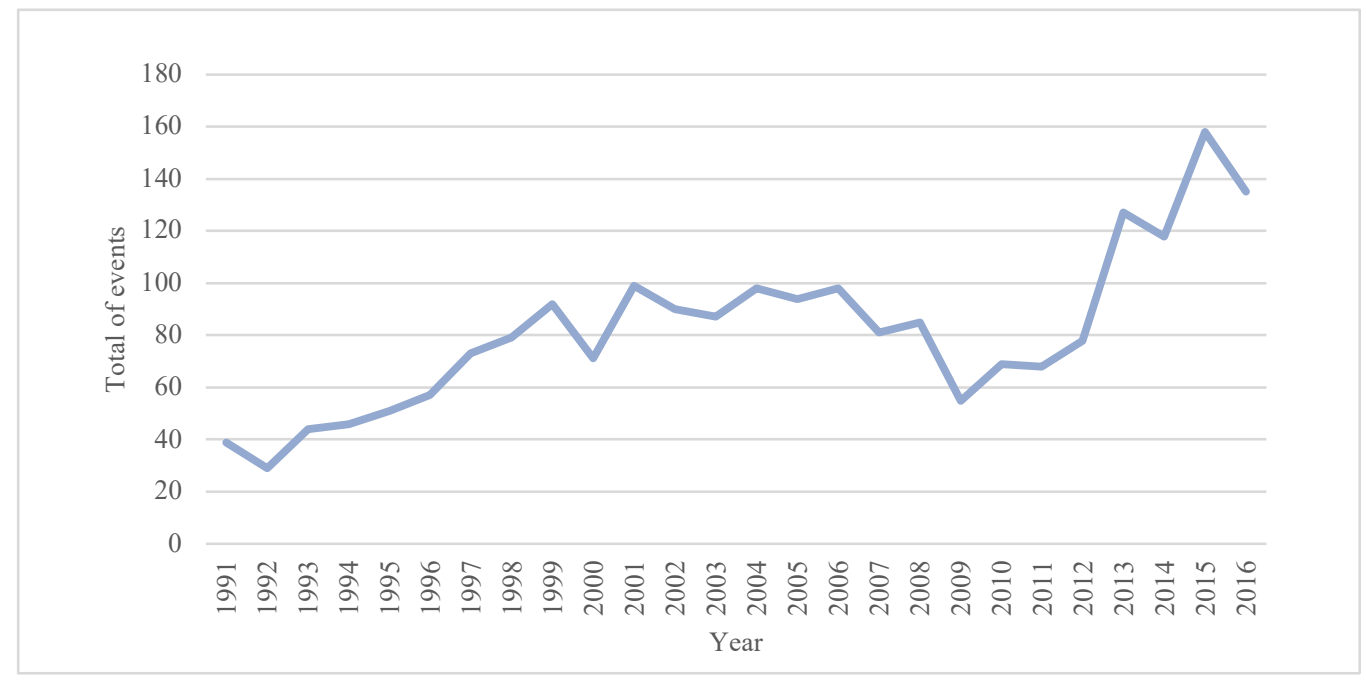

\section{RESULTS AND DISCUSSION}

\subsection{Unit Root Test Result}

The stationarity tests, the Augmented Dickey-Fuller (ADF) and the Phillips-Perron (PP) tests, were applied to examine the level of stationarity of the data. Table 2 shows that all of the variables under study are integrated at order I(0) and I(1). Then, the ARDL approach was employed, since the variables were integrated at different orders.

Table 1: The results of the Unit Root Tests

\begin{tabular}{|c|c|c|c|c|}
\hline & \multicolumn{4}{|c|}{ Test Statistics } \\
\hline & \multicolumn{2}{|c|}{ ADF } & \multicolumn{2}{|c|}{ PP } \\
\hline & Intercept & Trend \& Intercept & Intercept & Trend \& Intercept \\
\hline \multicolumn{5}{|c|}{ A: Level } \\
\hline LEVENT & $-2.660(2)^{*}$ & $-4.205(2)^{* * *}$ & $-6.865(8)^{* * *}$ & $-8.965(8)^{* * *}$ \\
\hline LTRECEIPT & $-1.386(5)$ & $-2.789(5)$ & $-1.152(3)$ & $-1.973(3)$ \\
\hline$L E X C$ & $-1.005(0)$ & $-1.479(0)$ & $-1.005(0)$ & $-1.595(1)$ \\
\hline$L G O V X$ & $-0.939(3)$ & $-0.928(3)$ & $-2.153(4)$ & $-11.027(4)^{* * *}$ \\
\hline$L C O P$ & $-1.223(0)$ & $-2.417(0)$ & $-1.173(2)$ & $-2.391(3)$ \\
\hline \multicolumn{5}{|c|}{ B: First Differences } \\
\hline$\triangle L E V E N T$ & $-7.222(3)^{* * *}$ & $-7.184(3)^{* * *}$ & $-25.301(9) * * *$ & $-25.084(9)^{* * *}$ \\
\hline
\end{tabular}




\begin{tabular}{lcccc}
\hline \hline & \multicolumn{3}{c}{ Test Statistics } \\
\cline { 2 - 5 } & \multicolumn{2}{c}{ ADF } & \multicolumn{2}{c}{ PP } \\
\cline { 2 - 5 } & Intercept & Trend \& Intercept & Intercept & Trend \& Intercept \\
\hline$\Delta L T R E C E I P T$ & $-3.617(4)^{* * *}$ & $-3.720(4)^{* *}$ & $-5.458(3)^{* * *}$ & $-5.481(3)^{* * *}$ \\
$\Delta L E X C$ & $-8.799(0)^{* * *}$ & $-8.772(0)^{* * *}$ & $-8.831(3)^{* * *}$ & $-8.806(3)^{* * *}$ \\
$\Delta L G O V X$ & $-8.687(3)^{* * *}$ & $-8.669(3)^{* * *}$ & $-31.693(4)^{* * *}$ & $-31.611(4)^{* * *}$ \\
$\Delta L C O P$ & $-8.842(1)^{* * *}$ & $-8.801(1)^{* * *}$ & $-9.664(4)^{* * *}$ & $-9.614(4)^{* * *}$ \\
\hline \hline
\end{tabular}

Note: $\Delta$ indicates the first difference. () represent the number of lag length. Asterisks $(* * *),(* *)$ and $(*)$ denote the statistical significance at the $1 \%, 5 \%$ and $10 \%$ levels, respectively, using the Mackinnon (1991) critical value.

\subsection{Autoregressive Distributed Lag (ARDL) Model}

From the unit root test result conducted in Table 2, the ARDL approach was used to investigate the presence of a long-term association between tourism event demand and its explanatory variables (tourist receipts, the exchange rate, government expenditure and the crude oil price).

The outcome of the F-statistic for cointegration shown in Table 3 is 8.105 which is larger than the critical value and lies above the upper bound. Hence, there is the occurrence of a long-run association among tourism receipts, the exchange rate, government expenditure and tourism event demand. Table 3, below, shows the result of the cointegration properties computed and the critical bounds which were obtained from Narayan (2005).

Table 2: Bounds Test Results

\begin{tabular}{cccc}
\hline \hline $\begin{array}{c}\text { Dependent } \\
\text { variable }\end{array}$ & \multicolumn{3}{c}{ Critical bounds (5\%) } \\
\cline { 2 - 4 }$D L E V E N T$ & F-statistic & Bottom & Top \\
\hline \hline
\end{tabular}

Source: Computed, critical bounds were obtained from Narayan (2005). *** denotes the significance at the $1 \%$ level.

In this section, we report the long-run estimations of our model. Based on Table 4, the AIC (Akaike Information Criterion) was chosen to determine the optimum ARDL order and the ARDL order was $(1,0,0,5,5)$.

Table 3: The Estimated ARDL Model of Event Tourism

\begin{tabular}{ccc}
\hline \hline Variables & Coefficient & Standard error \\
\hline Constant & -2.509 & $1.131^{* *}$ \\
$D L G O V X$ & 0.386 & 0.251 \\
$D L G O V X(-1)$ & -0.434 & 0.301 \\
$D L G O V X(-2)$ & 0.201 & 0.307 \\
$D L G O V X(-3)$ & 0.699 & $0.319^{* *}$ \\
$D L G O V X(-4)$ & 0.373 & $0.223^{* *}$ \\
$D L C O P$ & -0.004 & 0.177 \\
$D L C O P(-1)$ & 0.085 & 0.208 \\
$D L C O P(-2)$ & 0.216 & 0.207 \\
$D L C O P(-3)$ & 0.558 & $0.193^{* *}$
\end{tabular}




\begin{tabular}{ccc}
\hline \hline Variables & Coefficient & Standard error \\
\hline DLCOP $(-4)$ & 0.415 & $0.196^{* *}$ \\
LTECEIPT $(-1)$ & 0.278 & $0.162^{*}$ \\
$\operatorname{LEXC}(-1)$ & 0.431 & $0.218^{*}$ \\
LGOVX $(-1)$ & 0.357 & 0.240 \\
LCOP $(-1)$ & -0.471 & $0.153^{* *}$ \\
LEVENT $(-1)$ & -0.593 & $0.095^{* * *}$ \\
\hline Note: ***,** and * denote the statistical significance at the $1 \%, 5 \%$ and $10 \%$, levels respectively. \\
\hline R-square & 0.712 \\
R-adjusted & & 0.661 \\
F-statistic & & 13.728 \\
\hline \hline
\end{tabular}

According to Table 5, the long-run outcomes indicated that tourism receipts, the exchange rate and government expenditure were positively correlated with event demand, except for the crude oil price which had a negative association with tourism event demand. Empirically, the outcome implies that in the long-run, an escalation in tourism receipts of $1 \%$ increases the event demand by $0.419 \%$, while the exchange rate provides a $0.7755 \%$ increase in event demand, government expenditure offers a $0.625 \%$ increase, the crude oil price gives a $0.777 \%$ decrease in tourism event demand. The variables under study are statistically significantly related to event demand.

$$
\begin{array}{cccc}
L E V E N T=-4.282+0.419 L T R E C E I P T & 0.775 L E X C+0.625 L G O V X-0.756 L C O P \\
T=(-2.446) & (1.692)^{*} & (2.373)^{* *} & (1.664)^{*}
\end{array}
$$

Table 4: Long Run Estimates Results

\begin{tabular}{ccc}
\hline \hline Variables & Coefficient & Standard Error \\
\hline LTRECEIPT & 0.419 & $0.247^{*}$ \\
LEXC & 0.775 & $0.326^{* *}$ \\
LGOVX & 0.625 & $0.375^{*}$ \\
LCOP & -0.756 & $0.243^{* *}$ \\
Constant & -4.282 & $1.750^{* *}$ \\
\hline \hline
\end{tabular}

Note: $* * *, * *$ and $*$ denote the statistical significance at the $1 \%, 5 \%$ and $10 \%$ levels respectively.

As can be identified from Table 6, the $\mathrm{EC}_{\mathrm{t}-1}$ variable carries the expected negative sign, is less than one and is highly significant, indicating that there was a long-run and stable association within the variables under study. The absolute value of the coefficient of the $\mathrm{EC}_{\mathrm{t}-1}$ was -0.614 or $61.4 \%$ and suggested that about $96 \%$ of the event demand adjustment occurs after one year and 8 months. On this basis, it was concluded that event demand only depended on the burnt of short-run adjustment to bring about the long-run equilibrium.

The diagnostic checking is reported in Table 6 which consisted of the Jarque-Bera test (Normality test), serial correlation (LM test), misspecification of the functional form (RESET test), and the autoregressive conditional heteroscedasticity (ARCH test). All of the diagnostic tests indicated that the null hypothesis was accepted at the levels of significance of $1 \%, 5 \%$ and $10 \%$. This means that the model had an accurate functional form and that the model's residuals homoscedasticity, were normally distributed, not serially correlated and that misspecification did not exist. 
Table 5: Error Correction Model Results

\begin{tabular}{|c|c|c|}
\hline Variables & Coefficient & Standard Error \\
\hline DLTRECEIPT & 0.257 & 0.156 \\
\hline$D L E X C$ & 0.476 & $0.227 * *$ \\
\hline$D L G O V X$ & 0.356 & 0.251 \\
\hline $\operatorname{DLGOVX}(-1)$ & -0.630 & $0.142 * * *$ \\
\hline$D L G O V X(-2)$ & -0.502 & $0.129 * * *$ \\
\hline$D L G O V X(-3)$ & 0.298 & 0.229 \\
\hline$D L G O V X(-4)$ & 0.392 & $0.223^{*}$ \\
\hline$D L C O P$ & -0.021 & 0.117 \\
\hline $\operatorname{DLCOP}(-1)$ & -0.102 & 0.256 \\
\hline$D L C O P(-2)$ & -0.358 & 0.259 \\
\hline$D L C O P(-3)$ & 0.156 & 0.258 \\
\hline$D L C O P(-4)$ & 0.419 & $0.196^{* *}$ \\
\hline $\operatorname{ECT}(-1)$ & -0.614 & $0.099 * * *$ \\
\hline \multicolumn{2}{|l|}{ Ramsey's RESET } & $\begin{array}{l}\text { F-statistic: } \\
1.864(0.176)\end{array}$ \\
\hline \multicolumn{2}{|l|}{ Jarque-Bera test } & $\begin{array}{l}\text { JB-statistic: } \\
1.561(0.458)\end{array}$ \\
\hline \multicolumn{2}{|c|}{ Breusch-Godfrey LM test } & $\begin{array}{l}\text { F-statistic: } \\
0.307(0.689)\end{array}$ \\
\hline \multicolumn{2}{|c|}{ Heteroscedasticity (ARCH) Test } & $\begin{array}{l}\text { F-statistic: } \\
0.498(0.477)\end{array}$ \\
\hline
\end{tabular}

Note: The $\left({ }^{* * *}\right),\left({ }^{* *}\right)$ and $(*)$ represent the level of significance at the $1 \%, 5 \%$ and $10 \%$, levels respectively.

Then, the CUSUM (cumulative sum of recursive residuals) and CUSUM square tests were applied to evaluate the stability of event tourism based on the research area which is Malaysia. Figure 2 and Figure 3 displayed the outcomes of the CUSUM and CUSUM square tests in a graphical presentation. The outcomes showed that the CUSUM and CUSUM square tests stayed inside the critical bound representing the stability of event tourism in Malaysia

Figure 2: CUSUM

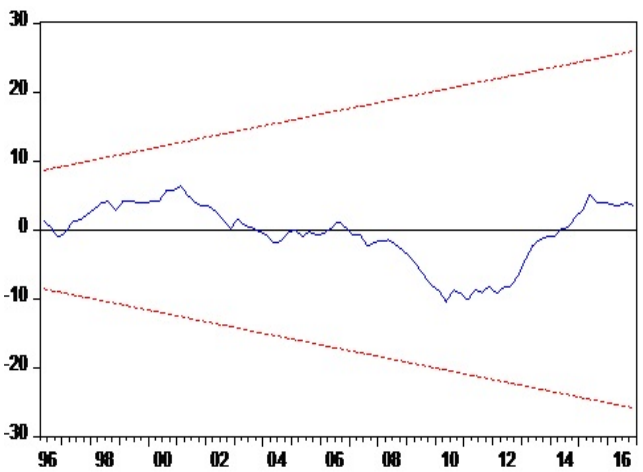

— CUSUM -.... 5\% Significance
Figure 3: CUSUM Square

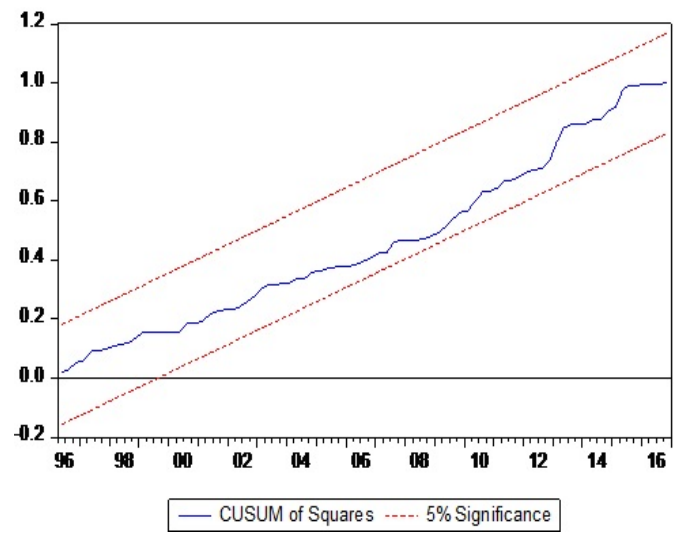


The Granger causality test was then employed to estimate the variables, by using the Wald test. Table 7 presents the outcomes for the short-run Granger causality test. Based on the table below, this study reported that the null hypothesis of no causal association among tourist receipts and tourism event demand was rejected at the significance level of $1 \%$. This specifies that these variables influenced tourism event demand in the short-run. Besides that, the exchange rate affected tourism event demand and it was not accepted at the significant level of $10 \%$. This indicates that these variables affected each other in the short-run. Therefore, the null hypothesis of no causal association among governement expenditure and tourism event demand was rejected at $1 \%$ the significance level. This indicates that these variables influence tourism event demand in the short-run. Other than that, the crude oil price influenced tourism event demand at the $10 \%$ significance level. As a whole, tourist receipts, the exchange rate, government expenditure and the crude oil price can all influence tourism event demand in Malaysia.

Table 6: Granger Causality Test

\begin{tabular}{lccc}
\hline \hline \multicolumn{1}{c}{ Null Hypothesis } & Chi-square & Probability & Result \\
\hline LTRECEIPT does not granger cause & 15.006 & {$[0.000]^{* * *}$} & LTRECEIPT $=>$ LEVENT \\
LEVENT & & & \\
LEXC does not granger cause LEVENT & 2.717 & {$[0.099]^{*}$} & LEXC $=>$ LEVENT \\
LGOVX does not granger cause & 53.056 & {$[0.000]^{* * *}$} & LGOVX $=>$ LEVENT \\
LEVENT & & & \\
LCOP does not granger cause LEVENT & 9.698 & {$[0.084]^{*}$} & LCOP $=>$ LEVENT \\
\hline \hline
\end{tabular}

Note: $* * *, * *$ and $*$ denote the statistical significance at the $1 \%, 5 \%$ and $10 \%$ levels respectively

The findings of this research found that there were significant and long-run links existing between the variables under study. The finding revealed a significant and positive association between tourism event demand and tourist receipts. The empirical finding agreed with prior literature (Salleh et al., 2008; Chaiptip \& Chaiboonsri, 2009; Hanafiah \& Harun, 2010; Habibi \& Abbasineiad, 2011; Muchhapondwa \& Pimhidzai, 2011; Surugiu, Leitao \& Surugiu, 2011). This indicated that higher tourist expenses on goods and services at competitive destinations, the demand for events staged in Malaysia tend to rise over the years, especially major events involving international visitors.

Besides that, the findings presented a significant and positive connection between tourism event demand and the exchange rate. The empirical results agreed with prior literature (Salleh et al., 2007; Salleh et al., 2008). Besides that, as for the exchange rate, if the exchange rate depreciates, meaning that the Malaysian Ringgit is appreciating, tourists would need to exchange more dollars for the same amount of Malaysian Ringgit. If tourists are satisfied with the tourism event, then, the tourists will have obtained good value for money.

Apart from that, the findings also showed a significant and positive association among tourism event demand and government expenditure. The inclusion of government expenditure is as a proxy for the government's allocation for event promotion and tourism infrastructure. The empirical findings agreed with prior literature (Ayob, 2003). This is because the government plays a role in maintaining infrastructure, promoting events and festivals; enriching the image of the destination and investing in facilities at destinations. 
Besides, the crude oil price was also added into the model and the findings show that there was a significant and negative connection between tourism event demand and the crude oil price. The empirical results agreed with prior literature (Chaitip \& Chaiboonsri, 2009; Muchapondwa \& Pimhidzai, 2011; Thien et al., 2015). This negative relationship can be clarified by considering that an increase in the crude oil price will indirectly rise transportation costs and airfares, which will discourage international visitors to travel to Malaysia. This is because tourists are very sensitive to changes in oil prices. Other than that, tourists may not have enough savings for them to travel. Hence, this will indirectly discourage tourists to attend activities, occasions and events hosted in Malaysia.

\section{CONCLUSION AND POLICY RECOMMENDATIONS}

The objective of this paper is to inspect the association between tourism event demand and selected macroeconomic variables. In other words, it attempts to determine the demand for tourism events in Malaysia. Tourist receipts, the exchange rate, government expenditure and the crude oil price were selected as the determinants of demand of event tourism in the model. A single cointegration technique, the ARDL approach, was applied to evaluate for the evidence of long-run association between the demand of event and its determinants. The findings of this research uncovered that there were significant and long-run relationships existing among tourist receipts, the exchange rate, government expenditure, the crude oil price and tourism event demand. The outcomes of this research showcase the presence of a beneficial relationship between the government and tourism industries, which can further benefit from collaborative policies for tourism events.

Firstly, tourism income is significant to ensure the development of tourism event and event tourism sustainability. Tourism income is also important, as the allocation of funds will further promote tourism events and encourage government involvement to play its role, in providing grants, subsidies and sponsorship. For example, Getz et al. (2012) indicated that the government, sponsors, and the media will closely monitor both the organisers and the events held to ensure that they are aligned with the objectives set for the tourism event. Also, additional tourism events could bring additional economic benefits to the country that in turn can improve the travel and tourism industry in Malaysia.

Meanwhile, event planners should diversify their promotion of new and unique events to new countries and markets to attract tourists from countries that can generate high tourist arrivals. The hosting of more diversified events is desirable to attract tourists from many different countries, despite the main focus targeting countries that can generate high tourist arrivals into Malaysia. For example, Ayob (2003) stated that the diversification of tourism events in term of size and complexity and the professions related to the events had demonstrably increased demand. Hence, such events should both boost economic performance and increase tourist arrivals.

In addition, government involvement, in the form of the Malaysia Tourism Promotion Board, should improve its service quality and upgrade Malaysia's brand image in promotional campaigns and programmes to ensure that it fulfils tourist's desires and wishes. For example, Ahmad et al. (2012) indicated that promotional campaigns should optimise media coverage and internet resources, such as tourism websites, Facebook, Twitter and Instagram. This is because nowadays travellers or tourists have high contact with media and internet resources, thus, significantly 
expanding tourist's participation. The Tourism Promotion Board should also, encourage private investors and large corporations to invest in the development of the tourism sector.

Other than that, another strategy that should be undertaken is the upgrading of connectivity and transportation services. Enhancing transportation connectivity, such as improving taxi services or ride-hailing services, Light Rail Transit (LRT) and buses. With improved connectivity, travelling would be better and quicker for visitors that intend to visit number of destinations. Hence, tourists will find it easier to attend and become involved in various events.

\section{ACKNOWLEDGEMENT}

The authors acknowledged the financial support rendered by the Ministry of Higher Education Malaysia via Universiti Malaysia Sarawak with a grant no. FRGS/SS01(01)/1292/2015(09) for research titled "Constructing model of patterns and trends of event tourism in Malaysia: Analytics application from temporal-spatial-thematic and time series".

\section{REFERENCES}

Ahmad, H., Jusoh, H., \& Azazi, N. A. N. (2012). Sustainability of youth tourists in event tourism: The Malaysian experiences. An International Multidisciplinary Journal of Tourism, 7(2), 503-526.

Ayob, N. (2003). An analysis of event tourism in Malaysia. ASEAN Journal on Hospitality and Tourism, 2(2), 92-102.

Ayob, N., \& Wahid, N. (2016). The growth and drivers of event tourism in Malaysia. In M. Marimuthu \& S. H. Hassan (Eds.), Consumption in Malaysia: Meeting of New Changes (pp. 129-141). Pulau Pinang, Malaysia: Universiti Sains Malaysia.

Chaitip, P., \& Chaiboonsri, C. (2009). Thailand's international tourism demand: The ARDL approach to cointegration. Annals of the University of Petrosani Economics, 9(3), 163184.

Cibinskiene, A. (2012). Impact evaluation of events as factors of city tourism competitiveness. Economics and Management, 17(4), 1333-1339.

Department of Statistic, Sarawak. (2015). Arrivals and departure statistic: Number of arrivals by citizenship to Sarawak. Malaysia: Department of Statistic.

Dickey, D. A. \& Fuller, W. A. (1981). Likelihood ratio statistics for autoregressive time series with a unit root. Econometrica, 49(4), 1057-1072.

Getz, D. (1989). Special events: Defining the product. Tourism management, 10(2), 125-137.

Getz, D. (2008). Event tourism: Definition, evolution, and research. Tourism Management, 29(3), 403-428.

Getz, D., \& Page, S. J. (2016). Progress and prospects for event tourism research. Tourism Management, 52(1), 593-631.

Habibi, F., \& Abbasinejad, H. (2011). Dynamic panel data analysis of European tourism demand in Malaysia. Iranian Economic Review, 15(29), 27-41.

Habibi, F., Rahim, K. A., Ramchandran, S., \& Chin, L. (2009). Dynamic model for international tourism demand for Malaysia: Panel Data Evidence. International Research Journal of Finance and Economics, 33(2), 1450-2887. 
Hanafiah, M. H. M., \& Harun, M. F. H. (2010). Tourism demand in Malaysia: A cross-sectional pool time series analysis. International Journal of Trade, Economic and Finance, 1(1), 80-90.

Kadir, N., \& Karim, M. Z. A. K. (2012). Tourism and economic growth in Malaysia: Evidence from tourist arrivals from Asean-5 countries. Economic Research-Ekonomska Istrazivanja, 25(4), 1089-1100.

Kusni, A., Kadir, N., \& Nayan, S. (2013). International tourism demand in Malaysia by tourists from OECD countries: A panel data econometric analysis. Economics and Finance, 7(1), 28-24.

Lean, H. H., Chong, S. H., \& Hooy, C. (2014). Tourism and economic growth: Comparing Malaysia and Singapore. International Journal of Economics and Management, 8(1), 139-157.

Li, C. C., Mahmood, R., Abdullah, H., \& Chuan, O. S. (2013). Tourism, selected macroeconomics variables and economic growth: An econometrics of long run and short run relationship. International Journal of Economics and Management, 7(1), 67-83.

McArdle, K. (1998). Temporal, Spatial and Thematic Analysis of Special Events in Victoria (Master dissertation, The Victoria University of Technology, Melbourne, Australia). Retrieved from http://vuir.vu.edu.au/id/eprint/15260

Menegaki, A. N. (2019). The ARDL method in the energy-growth nexus field; best implementation strategies. Economies, 7(105), 1-16.

Muachapondwa, E., \& Pimhidzai, O. (2011). Modelling international tourism demand for Zimbabwe. International Journal of Business and Social Science, 2(2), 1-15.

Narayan, P. K. (2005). The saving and investment nexus for China: Evidence from cointegration test. Applied Economics, 37(17), 1979-1990.

Ooi, C. A., Hooy, C. W., \& Som, M., \& Puad, A. (2013). Tourism crises and state level tourism demand in Malaysia. International Journal of Business and Society, 14(3), 376-389.

Oklobdzija, S. (2015). The role of events in tourism development. Часопис БизИнфо, 6(2), 8397.

Pesaran, M. H., Shin Y., \& Smith, R. J. (2001). Bound testing approaches to the analysis of level relationships. Journal of Applied Econometrics, 16(3), 289-326.

Phillips, P. C., \& Perron, P. (1988). Testing for a unit root in time series regression. Biometrika, 75(2), 335-346.

Salleh, N. H. M., Law, S. H., Ramachandran, S., Shuib, A., \& Noor, Z. M. (2008). Asian tourism demand for Malaysia: A bound test approach. Contemporary Management Research, 4(4), 351-368.

Surugiu, C., Leitao, N. C., \& Surugiu, M. R. (2011). A panel data modelling of international tourism demand: Evidence for Romania. Economic Research-Ekonomska Istrazivanja, 24(1), 134-145.

Thien, F. T., Puah, C. H., Hassan, M. K. H., \& Arip. M. A. (2015). An ECM analysis of Thai tourism demand in Malaysia. Mediterranean Journal of Social Sciences, 6(3), 162-168.

Yusof, A. M., Fazil, F., Mohamed, N. R. W., Ibrahim, Z., \& Talib, A. H. (2015). Awareness of the emerging event industry among tourism students in Malaysia. International Journal of Economics, Commerce and Management, 3(2), 1-11. 